\title{
Genetic Studies on Productive and Reproductive Traits of Crossbred Jersey (Jersey $\times$ Nondescript) Cattle
}

\author{
Periyasamy Vijayakumar ${ }^{1}$, Athinarayanan Paramasivam ${ }^{1}$, Arunasalam Singaravadivelan ${ }^{1}$, \\ Thiagarajan Sivakumar ${ }^{2}$, Thangavelu Vasanthakumar ${ }^{1}$, Ramasamy Nithiaselvi ${ }^{1}$ and Richard Churchil ${ }^{3}$ \\ ${ }^{1}$ Livestock Farm Complex, Veterinary College and Research Institute, TANUVAS, Orathanadu, Tamil Nadu, INDIA \\ ${ }^{2}$ Veterinary College and Research Institute, TANUVAS, Orathanadu, Tamil Nadu, INDIA \\ ${ }^{3}$ Directorate of Research, TANUVAS, Madhavaram Milk Colony, Chennai, Tamil Nadu, INDIA
}

*Corresponding author: P Vijayakumar; E-mail: nayaganviji@gmail.com

"Periyasamy Vijayakumar and Singaravadivelan contributed equally to this work"

Received: 22 June, 2021

Revised: 25 July, 2021

Accepted: 27 July, 2021

\begin{abstract}
The southern Indian states depend mainly on crossbred cattle for milk production. For maintaining a high level of milk productivity of crossbred cattle and their further genetic improvement, it is necessary to know the genetic parameters and influence of various non-genetic and genetic factors on economic traits. Hence, in the present study, we estimated the heritability and influence of non-genetic factors on production and reproduction traits in crossbred Jersey cattle (Jersey $\times$ nondescript). The overall leastsquares means ( \pm standard error) of age at first calving (days), calving interval (days), services per conception, service period (days), dry period (days), lactation milk yield (liters), and lactation length (days) were $1057.83 \pm 21.25,449.52 \pm 8.55,2.55 \pm 0.11$, $176.31 \pm 7.67,130.27 \pm 6.73,2265.24 \pm 63.44$, and $318.61 \pm 5.62$ respectively. Period of calving had a significant $(\mathrm{p}<0.05)$ effect on all economic traits studied except the dry period. Calving interval and service period were affected by the season of calving. The heritability estimates of age at first calving, calving interval, services per conception, service period, dry period, lactation milk yield, and lactation length were $0.289 \pm 0.06,0.306 \pm 0.09,0.123 \pm 0.18,0.329 \pm 0.33,0.381 \pm 0.48,0.508 \pm 0.88$, and $0.455 \pm 0.45$ respectively. This information will be useful to disclose action plans to make scientific interventions on the production and reproduction of crossbred Jersey cattle to exploit its maximum genetic potential.
\end{abstract}

\section{HIGHLIGHTS}

(0 The overall least-squares means and heritability for various economic traits were estimated.

(0 Period of calving had a significant effect on all traits except dry period.

Keywords: Crossbred Jersey, heritability, period, season, parity, traits

Dairying has become an important secondary source of income-generating and employing millions of marginal and women farmers in India (Vijayakumar et al., 2019; Singaravadivelan et al., 2021). Crossbreeding of highyielding exotic milch cattle breeds with indigenous nondescript cattle has emerged as an effective and suitable strategy to increase milk production in non-descript cattle (Singh et al., 2016). In the absence of milch cattle breeds in south India, the southern Indian states depend mainly on crossbred cattle for milk production. As per the $20^{\text {th }}$ Livestock Census, Tamil Nadu has 95.19 lakh cattle and 5.19 lakh buffaloes. Out of this, $81.15 \%$ are crossbred and exotic cattle, and $18.85 \%$ are indigenous cattle (Anon, 2020). Further, this state has a robust breeding policy that encourages the farmers for rearing the cross-bred Jersey cattle in the plains region of Tamil Nadu.

For maintaining a high level of milk production/ productivity of crossbred cattle and their further

How to cite this article: Vijayakumar, P., Paramasivam, A., Singaravadivelan, A., Sivakumar, T., Vasanthakumar, T., Nithiaselvi, R. and Churchil, R. (2021). Genetic Studies on Productive and Reproductive Traits of Crossbred Jersey (Jersey $\times$ nondescript) cattle. J. Anim. Res. 11(04): 653-659.

Source of Support: None; Conflict of Interest: None
क $\odot$ 
improvement, it is necessary to know the genetic parameters, the influence of various non-genetic and genetic factors on various production and reproduction traits (Ali et al., 2019). Frequent updating of the available knowledge of genetic parameters, factors influencing various economic traits in crossbred cattle is an important and recommended practice in crossbred cattle breeding programs (Caetano et al., 2013). However, a very limited number of reports are available for crossbred Jersey cattle (Jersey x nondescript). Hence, the present investigation was undertaken to study the estimation of heritability and influence of various non-genetic factors on production and reproduction traits in crossbred Jersey cattle. This study will be valuable to suggest suitable selection programs and breeding strategies along with management practices for genetic improvement of crossbred Jersey cattle under the Cauvery delta region of Tamil Nadu state.

\section{MATERIALS AND METHODS}

\section{Herd Structure}

The present study was carried out at the Dairy unit of Livestock Farm Complex, Veterinary College and Research Institute, Orathanadu, Tamil Nadu, India. The Dairy Unit was established under National Agriculture Development Programme (NADP) sponsored scheme on 'Establishing Nucleus Jersey Crossbred Bull-Mother Farm'. Crossbred Jersey cows (Jersey x nondescript) were purchased based on phenotypic characters and production records (personal recording of milk yield during peak lactation) from milk shed areas in Vellore, Thiruvannamalai, Namakkal, Madurai, Erode, and Theni districts of Tamil Nadu. The exact genetic composition (inheritance level of Jersey/ non-descript) of these crossbred cows is unknown. This population constitutes of various inheritances level of Jersey and non-descript cross.

\section{Farm Management Practices}

All crossbred Jersey animals were kept in the same environment with similar management practices. All animals were kept under an intensive system of management. The newborn calves were weaned on dayold and pail milk feeding was practiced. The adult animals were fed with $20-30 \mathrm{~kg}$ green fodder and 5-7 $\mathrm{kg}$ of dry fodder daily. The concentrate feed of $2 \mathrm{~kg}$ was provided for maintenance and additional feed was given at the rate of $400 \mathrm{~g}$ for every $\mathrm{kg}$ of milk production. Milking was carried out twice a day at $12 \mathrm{hrs}$ intervals. Periodical disease screening for Tuberculosis, Johne's disease, and Brucellosis were carried out. Animals were vaccinated against Foot-and-mouth disease and Hemorrhagic septicemia. Animals were observed for estrus signs and artificial insemination was carried out after $12 \mathrm{hrs}$ of the onset of estrus signs.

\section{Data Analysis}

The data collected from the farm records for a period of 8 years from 2013 to 2021 was taken for this study. A total of 350 records obtained from 115 crossbred Jersey cattle were analyzed to assess the production and reproduction performance of crossbred Jersey cattle. Incomplete records due to death or disposal were eliminated from the analysis. To ensure the normal distribution, the outliers beyond two-standard deviation on both the tail of the distribution were expelled from the original data. The economic traits studied were lactation length (days), lactation milk yield (liters), age at first calving (days), calving interval (days), services per conception, dry period (days), and service period (days). The factors studied were a period of birth, a season of birth, period of calving, the season of calving, and parity. The Year of calving was divided into three periods (2013-2015, 2016-2018, and 2019-2021). Four calving seasons were defined: cold weather period (JanFeb), summer (Mar-May), southwest monsoon season (Jun-Sep), and northeast monsoon season (Oct-Dec). Parity was divided into six groups (first, second, third, fourth, fifth, and sixth and above parity).

The general linear model analysis implemented in the IBM SPSS Statistics package was used to estimate and study the effect of non-genetic factors on various production and reproduction traits in crossbred Jersey cattle. The following models were used:

\section{For age at first calving}

$$
Y_{i j k}=\mu+S_{i}+P_{j}+e_{i j k}
$$

Where, $Y_{i j k}=$ Age at first calving of the $k^{\text {th }}$ heifer, born in the $i^{\text {th }}$ period, and $j^{\text {th }}$ season, $\mu=$ Overall population mean, 
$S_{i}=$ Effect of the $i^{\text {th }}$ season $(i=1-4), P_{j}=$ Effect of the $j^{\text {th }}$ period $(j=1-3)$ and $e_{i j k}=$ Random error, $\operatorname{NID}\left(0, \sigma^{2} e\right)$.

\section{For other economic traits}

$$
Y_{i j k l}=\mu+S_{i}+P_{j}+A_{k}+e_{i j k l}
$$

Where $Y_{i j k l}=$ response variable on the $l^{\text {th }}$ individual in $i^{\text {th }}$ season, $j^{\text {th }}$ period and $k^{\text {th }}$ parity.

$\mu=$ Overall population mean

$S_{i}=$ Effect of the $i^{\text {th }}$ season $(i=1-4)$

$P_{j}=$ Effect of $j^{\text {th }}$ period $(j=1-3)$

$A_{k}=$ Effect of parity $(k=1-6)$

$e_{i j k l}=$ Random error, NID $\left(0, \sigma^{2} e\right)$

The least-square (LS) means were compared through Tukey's Honest Significant Difference test for testing differences among LS means. Heritability and (co) variance components were estimated by restricted maximum likelihood (REML) fitting an animal model (Meyer, 2007). The fixed non-genetic factors that were found to be significant $(\mathrm{P}<0.05)$ from the least-squares analyses were fitted for each trait to estimate heritability.

\section{RESULTS AND DISCUSSION}

The age at first calving (AFC) and calving interval (CI) is the main economic traits in lactating animals and lesser $\mathrm{AFC}$ and $\mathrm{CI}$ increase the economic profit in the dairy animal in terms of the number of calf crops per cow. The mean age at first calving estimated in the present study was $1057.83 \pm 21.25$ days (Table 1) and the period of born had a significant effect on AFC which was support in Singh and Raut (1980). While Hadge et al. (2009) and Vinothraj et al. (2016) reported a non-significant effect of the period of born on this trait. The non-significant effect of season of born on this trait is in close agreement with Govindaiah et al. (1998) and Deokar and Ulmek (1999). This estimated LS mean of AFC was lower in comparison with Sahiwal $\times$ Jersey (Hadge et al., 2009), Jersey $\mathrm{x}$ Sahiwal (Varaprasad et al., 2013) and Jersey x Red Sindhi (Vinothraj et al., 2016) crossbred cows. The mean calving interval estimated from the data is $449.52 \pm 8.55$ days. The overall calculated LS mean in the present study was lower in comparison with Mondal et al. (2005); Hadge et al.
(2009); Dandapat et al. (2010); and Vinothraj et al. (2016). In contrast, Hussain et al. (2012) reported 393.68 \pm 1.64 days as calving interval for Jersey $\times$ Local cross cows. The least-square analysis shows that period of calving and the seasons of calving have a significant effect on calving interval. In confirmatory with the present findings Gogoi (1991), Das (1995) and Hussain et al. (2012) reported a significant effect of season of calving, and Hadge et al. (2009) reported a significant effect of the period of calving on this trait. In contrast, Vinothraj et al. (2016) reported a non-significant effect of the period of calving and seasons of calving on this trait.

The number of services required per conception is important in the breeding management of dairy cattle and it depends on management, breeding, and environmental effects. The period of calving had a significant effect and the season of calving and parity has a non-significant effect on this trait. Sultana (1995) observed non-genetic factors had no significant effect on service per conception in exotic cattle breeds and their crosses. In the present study, the number of service per conception is $2.55 \pm 0.11$ (Table 1) and it's higher than the earlier reports for crossbred Jersey cows which ranged from 1.52 to 2.5 (Mondal et al., 2005; Haque et al., 2011; Goni et al., 2015; Vinothraj et al., 2016).

The service period play important role in the number of calves produced in the productive lifespan of dairy cattle. The LS mean of the service period of crossbred Jersey cattle was $176.31 \pm 7.67$ days (Table 2) which is in close agreement with the results of Subramanian \& Ulaganathan (1990) and Vinothraj et al. (2016) for Jersey-Red Sindhi crossbred cows. However, this LS mean is longer in comparison with Jersey $\times$ Local cows (Hussain et al., 2012) and shorter than Sahiwal $x$ Jersey crossbred cows (Hadge et al., 2009). The season of calving and period of calving has a significant effect on the service period which was in support with Hussain et al. (2012). However, contrary to present observation Singh and Raut (1980), Hadge et al. (2009) and Vinothraj et al. (2016) did not observe a significant effect on this trait. The overall mean dry period of crossbred Jersey was $130.27 \pm 6.73$ days (Table 2), which is in close agreement with findings of Vinothraj et al. (2016) for Jersey x Red Sindhi crossbred cows. However longer dry period was reported for Sahiwal x Jersey crossbred cows (Hadge et al., 2012) and a shorter dry period was reported for different genetic groups of 
Table 1: Least squares means along with their standard errors for non-genetic factors affecting the age at first calving (days), calving interval (days) and services per conception traits in crossbred Jersey cattle

\begin{tabular}{lllllll}
\hline \multirow{2}{*}{ Effect } & \multicolumn{2}{c}{ Age at first calving (days) } & \multicolumn{2}{c}{ Services per conception } & \multicolumn{2}{c}{ Calving interval (days) } \\
\cline { 2 - 7 } & $\mathbf{n}$ & Mean \pm SE & $\mathbf{n}$ & Mean \pm SE & n & Mean \pm SE \\
\hline Overall mean $(\mu)$ & 53 & $1057.83 \pm 21.25$ & 306 & $2.55 \pm 0.11$ & 198 & $449.52 \pm 8.55$ \\
Period of calving & - & $*$ & - & $*$ & $*$ & $*$ \\
P1 (2013-15) & 15 & $955.05 \pm 39.49^{\mathrm{b}}$ & 102 & $3.25 \pm 0.19^{\mathrm{a}}$ & 61 & $484.34 \pm 15.60^{\mathrm{b}}$ \\
P2 (2016-18) & 17 & $1149.54 \pm 35.95^{\mathrm{a}}$ & 118 & $2.39 \pm 0.16^{\mathrm{b}}$ & 95 & $446.56 \pm 10.95^{\mathrm{a}}$ \\
P3 (2019-21) & 21 & $1068.91 \pm 31.61^{\mathrm{a}}$ & 86 & $2.01 \pm 0.21^{\mathrm{b}}$ & 42 & $417.65 \pm 16.10^{\mathrm{a}}$ \\
Season of calving & - & $\mathrm{NS}$ & - & $\mathrm{NS}$ & - & $*$ \\
Cold weather period (Jan-Feb) & 7 & $1122.44 \pm 55.10$ & 65 & $2.43 \pm 0.21$ & 21 & $468.79 \pm 22.63^{\mathrm{a}}$ \\
Summer (Mar-May) & 15 & $1007.42 \pm 37.46$ & 48 & $2.48 \pm 0.25$ & 53 & $445.75 \pm 14.16^{\mathrm{ab}}$ \\
South West monsoon season (Jun-Sep) & 17 & $1023.06 \pm 34.96$ & 108 & $2.69 \pm 0.17$ & 63 & $471.69 \pm 13.03^{\mathrm{b}}$ \\
North East monsoon season (Oct-Dec) & 14 & $1078.42 \pm 39.17$ & 85 & $2.59 \pm 0.19$ & 61 & $411.84 \pm 13.19^{\mathrm{c}}$ \\
Parity & - & - & - & $\mathrm{NS}$ & - & $\mathrm{NS}$ \\
First & - & - & 102 & $2.37 \pm 0.17$ & 34 & $484.50 \pm 17.32$ \\
Second & - & - & 51 & $2.27 \pm 0.25$ & 42 & $442.15 \pm 16.57$ \\
Third & - & - & 53 & $2.61 \pm 0.24$ & 37 & $442.38 \pm 17.10$ \\
Fourth & - & - & 42 & $2.37 \pm 0.27$ & 37 & $446.79 \pm 17.88$ \\
Fifth & - & - & 29 & $2.65 \pm 0.32$ & 26 & $426.61 \pm 21.48$ \\
Sixth and above & - & - & 29 & $3.01 \pm 0.32$ & 22 & $454.67 \pm 22.79$ \\
\hline
\end{tabular}

$\left({ }^{*} \mathrm{p}<0.05\right.$. Means having same superscript does not differ significantly $(\mathrm{p}>0.05) . \mathrm{n}=$ Number of observations, NS=Not significant, $\mathrm{SE}=\mathrm{Standard}$ error).

Table 2: Least squares means along with their standard errors for non-genetic factors affecting the service period (days), dry period (days), lactation milk yield (liters), and lactation length (days) traits in crossbred Jersey cattle

\begin{tabular}{|c|c|c|c|c|c|c|c|c|}
\hline \multirow[t]{2}{*}{ Effect } & \multicolumn{2}{|c|}{$\begin{array}{l}\text { Dry period } \\
\text { (days) }\end{array}$} & \multicolumn{2}{|c|}{$\begin{array}{l}\text { Service period } \\
\text { (days) }\end{array}$} & \multicolumn{2}{|c|}{$\begin{array}{c}\text { Lactation milk yield } \\
\text { (liters) }\end{array}$} & \multicolumn{2}{|c|}{$\begin{array}{c}\text { Lactation length } \\
\text { (days) }\end{array}$} \\
\hline & $\bar{n}$ & Mean \pm SE & $\mathbf{n}$ & Mean \pm SE & n & Mean \pm SE & $\mathbf{n}$ & Mean \pm SE \\
\hline Overall mean $(\mu)$ & 195 & $130.27 \pm 6.73$ & 229 & $176.31 \pm 7.67$ & 241 & $2265.24 \pm 63.44$ & 216 & $318.61 \pm 5.62$ \\
\hline Period of calving & - & NS & - & * & - & $*$ & - & * \\
\hline P1 (2013-15) & 74 & $129.65 \pm 11.57$ & 71 & $207.56 \pm 14.56^{\mathrm{a}}$ & 90 & $2660.59 \pm 112.11^{\mathrm{a}}$ & 67 & $354.43 \pm 10.65^{\mathrm{a}}$ \\
\hline P2 (2016-18) & 85 & $124.34 \pm 8.85$ & 97 & $164.32 \pm 10.95^{\mathrm{b}}$ & 95 & $2441.93 \pm 92.71^{\mathrm{a}}$ & 94 & $323.07 \pm 7.98^{\mathrm{b}}$ \\
\hline P3 (2019-21) & 36 & $136.83 \pm 13.23$ & 61 & $157.04 \pm 14.26^{\mathrm{b}}$ & 56 & $1693.19 \pm 124.05^{\mathrm{b}}$ & 55 & $278.33 \pm 10.74^{\mathrm{c}}$ \\
\hline Season of calving & - & NS & - & $*$ & - & NS & - & NS \\
\hline Cold weather period (Jan-Feb) & 21 & $154.48 \pm 17.52$ & 28 & $195.41 \pm 19.99^{\mathrm{a}}$ & 28 & $2237.11 \pm 167.97$ & 27 & $318.35 \pm 14.63$ \\
\hline Summer (Mar-May) & 49 & $132.11 \pm 11.51$ & 63 & $183.30 \pm 13.21^{\mathrm{ab}}$ & 71 & $2394.30 \pm 105.31$ & 59 & $323.43 \pm 9.82$ \\
\hline South West monsoon season (Jun-Sep) & 63 & $129.15 \pm 10.21$ & 72 & $190.01 \pm 12.38^{\mathrm{ab}}$ & 76 & $2297.65 \pm 102.00$ & 66 & $326.45 \pm 9.31$ \\
\hline North East monsoon season (Oct-Dec) & 62 & $105.35 \pm 10.13$ & 66 & $136.50 \pm 12.97^{\mathrm{ac}}$ & 66 & $2131.88 \pm 108.24$ & 64 & $306.22 \pm 9.37$ \\
\hline Parity & - & NS & - & NS & - & NS & - & NS \\
\hline First & 36 & $160.65 \pm 13.00$ & 43 & $196.59 \pm 16.04$ & 48 & $2090.11 \pm 127.53$ & 41 & $323.32 \pm 11.80$ \\
\hline Second & 44 & $121.78 \pm 12.86$ & 44 & $198.76 \pm 16.48$ & 47 & $2241.39 \pm 137.13$ & 39 & $323.03 \pm 12.51$ \\
\hline Third & 40 & $129.56 \pm 12.91$ & 44 & $159.77 \pm 16.07$ & 49 & $2273.89 \pm 129.97$ & 41 & $318.30 \pm 11.91$ \\
\hline Fourth & 33 & $124.53 \pm 14.59$ & 40 & $160.73 \pm 17.40$ & 40 & $2399.27 \pm 147.16$ & 39 & $316.86 \pm 12.76$ \\
\hline Fifth & 24 & $111.75 \pm 17.10$ & 28 & $155.49 \pm 21.12$ & 31 & $2369.99 \pm 168.68$ & 31 & $319.74 \pm 14.49$ \\
\hline Sixth and above & 18 & $133.37 \pm 19.17$ & 30 & $186.51 \pm 19.90$ & 26 & $2216.77 \pm 176.97$ & 25 & $310.41 \pm 15.45$ \\
\hline
\end{tabular}

${ }^{*} \mathrm{p}<0.05$. Means having same superscript does not differ significantly $(\mathrm{p}>0.05)$. $\mathrm{n}=$ Number of observations, $\mathrm{NS}=\mathrm{Not}$ significant, $\mathrm{SE}=\mathrm{Standard}$ error. 
Table 3: Heritability estimates along with their standard error for various production and reproduction traits in crossbred Jersey cattle

\begin{tabular}{lllll}
\hline Traits & Error variance & Phenotypic variance & Additive genetic variance & Heritability \\
\hline Age at first calving & 15039 & 21140.3 & 6101.23 & $0.289 \pm 0.06$ \\
Services per conception & 1.85205 & 2.11237 & 0.260321 & $0.123 \pm 0.18$ \\
Calving interval & 7161.62 & 10316.4 & 3154.79 & $0.306 \pm 0.09$ \\
Dry period & 5274.48 & 8518.42 & 3243.94 & $0.381 \pm 0.48$ \\
Service period & 8641.07 & 12875.3 & 4234.18 & $0.329 \pm 0.33$ \\
Lactation milk yield & 243623 & 494912 & 251289 & $0.508 \pm 0.88$ \\
Lactation length & 2395.8 & 4392.44 & 1996.64 & $0.455 \pm 0.45$ \\
\hline
\end{tabular}

cows (Haque et al., 2011). All the non-genetic factors such as period of calving, the season of calving, and parity have a non-significant effect on this trait which was supported in Vinothraj et al. (2016).

The overall mean of lactation milk yield of crossbred Jersey cows is $2265.24 \pm 63.44$ liters (Table 2). Further, this lactation yield was higher in comparison with Jersey crosses such as Jersey $\times$ Local, Jersey $\times$ Friesian, crossbred Jersey, and Sahiwal $\times$ Jersey crossbred cows (Haque et al., 2011; Hadge et al., 2012; NDDB, 2014). The period of calving had a significant effect on lactation milk yield. The season of calving and parity does not significantly affect the milk yield. The present estimate for lactation length in Sahiwal cows is similar to those reported by Deshmukh et al. (1995) for Jersey $\times$ Friesian crosses, while Mondal et al. (2005) and Hadge et al. (2012) reported lower estimates of lactation length. Dandapat et al. (2010) reported higher estimates of lactation length for crossbred cattle $(\mathrm{HF} \times$ Jersey $\times$ Sahiwal) than the present findings. The period of calving had a significant effect and the season of calving and parity does not significantly affect the lactation length.

\section{Heritability}

The heritability estimate of age at first calving was $0.289 \pm 0.06$ in the present study (Table 3 ), which was most closely in agreement with the heritability estimate of crossbred cows (Dubey and Singh, 2005; Vinothraj et al., 2016). Heritability estimates of calving interval estimated in this study was $0.306 \pm 0.09$ (Table 3). Gaikwad-inamdar and Narayankhedkar (2002) reported similar heritability estimates $(0.39 \pm 0.28)$ for crossbreed (Gir $\times$ Holstein Friesian and Gir $\times$ Jersey) cows. Vinothraj et al. (2016) and Ali et al. (2019) reported lower heritability estimates for calving intervals in different grades of dairy cattle and
Sahiwal cows respectively. The heritability estimates for services per conception $(0.123 \pm 0.18)$ of crossbred Jersey herd (Table 3) are higher than the earlier report (Vinothraj et al., 2016). The service period is an important trait of dairy animals and directly impacts the calving interval period. The estimated heritability of the service period is $0.329 \pm 0.33$ (Table 3), which was in close agreement with the results of Dubey and Singh (2005) for Sahiwal and crossbred cows. However, lower estimates of heritability were reported for Jersey $\times$ Red Sindhi crossbreds (Vinothraj et al., 2016). The present study lactation milk yield heritability estimate was $0.508 \pm 0.88$ for crossbred Jersey herd. However, Rehman et al. (2008) reported a lower heritability estimate of $0.11 \pm 0.03$ of lactation yield for Sahiwal cows. Previous works of the literature showed that heritability estimates of the lactation milk yield ranged widely from 0.06 to 0.69 (Dubey and Singh, 2005; Cilek and Sahin, 2009; Hadge et al., 2012; Singh and Singh, 2016; Ali et al., 2019). The heritability estimate of lactation length for crossbred Jersey herd was $0.455 \pm 0.45$ (Table 3). However, Hadge et al. (2012) reported higher heritability estimates of $0.919+0.503$ for Sahiwal $\times$ Jersey crossbred cows and Ali et al. (2019) reported lower heritability estimates of $0.04 \pm 0.212$ for different breeds.

\section{CONCLUSION}

In conclusion, our results indicate the effect of non-genetic factors such as period, season, and parity on production and reproduction traits in crossbred Jersey cattle. The heritability and LS mean obtained for various economic traits provide inputs to refine selection programs and breeding strategies along with management practices for genetic improvement of crossbred Jersey cattle of Tamil Nadu state. 


\section{ACKNOWLEDGEMENTS}

The contributions of the staff of Veterinary College and Research Institute, Orathanadu, in recording and maintenance of data are acknowledged.

\section{REFERENCES}

Ali, I., Muhammad, S.S. and Shafiq, M. 2019. Heritability estimates and genetic correlations of various production and reproductive traits of different grades of dairy cattle reared under subtropical condition. Reprod. Dom. Anim., 54: 10261033.

Anonymous. 2020. Policy Note - 2020-2021. Animal Husbandry, Dairying and Fisheries Department, Government of Tamil Nadu, Chennai, Tamil Nadu, India.

Caetano, S.L., Savegnago, R.P., Boligon, A.A., Ramos, S.B., Chud, T.C.S., LÔbo, R.B. and Munari, D.P. 2013. Estimates of genetic parameters for carcass, growth and reproductive traits in Nellore cattle. Livest. Sci., 155: 1-7.

Cilek, S. and Sahin, E. 2009. Estimation of some genetic parameters (heritability and repeatability) for milk yield in the Anatolian population of Holstein cows. Arch. Zootech., 12: $57-64$.

Dandapat, A., Banerjee, D. and Chakraborty, D. 2010. Genetic studies on various production and reproduction traits of Sahiwal and crossbred cattle (HF $\times$ Jersey $\times$ Sahiwal $)$ of an organised farm. Vet. World, 3(4): 167-168.

Das, G.C. 1995. Life time performance of different genetic groups of cattle in Assam. Ph.D. Thesis submitted to Assam Agricultural University, Khanapara, Assam.

Deokar, D.K. and Ulmek, B.R. 1999. Age at first calving in Jersey cattle. Indian Vet. J., 76: 338-339.

Dubey, P.P. and Singh, C.V. 2005. Estimates of genetic and phenotypic parameters considering first lactation performance traits in Sahiwal cattle and crossbred cattle. Indian J. Anim. Sci., 75(11): 1289-1294.

Gaikwad-Inamdar, S. and Narayankhkdar, S.G. 2000. Estimation of heritability of reproduction traits in crossbred cows. Indian Vet. J., 77(9): 811-812.

Gogoi, D.N. 1991. Genetic evaluation of Jersey, Red Sindhi and Jersey $\times$ Red Sindhi cattle in Assam. M.V.Sc. Thesis submitted to Assam Agricultural University, Ghuwahati, Assam.

Goni, S., Muller, C.J.C., Dube, B. and Dzama, K. 2015. Reproductive performance of Jersey and Fleckvieh $\times$ Jersey heifers and cows maintained on a pasture-based feeding system. S. Afr. J. Anim. Sci., 45(4): 379-385.
Govindaiah, M.G., Harish, S.N., Murhy, H.N.N., Jayashankar, M.R. and Rao, G.M. 1998. Genetic Studies on age at sexual maturity and age at first calving in Jersey cattle. Indian Vet. J., 75: 1102-1105.

Hadge, M.R., Kuralkar, S.V., Ali, S.Z. and Kharkar, K.P. 2009. Performance of Sahiwal and its Jersey crosses for reproductive traits in different lactations. Indian J. Anim. Res., 43(1): 75-76.

Hadge, M.R., Kuralkar, S.V., Ali, S.Z., Kharkar, K.P. and Sawaimul, A.D. 2012. Genetic studies on productive traits of Sahiwal and Sahiwal $\times$ Jersey crossbred cows. Indian $J$. Anim. Res., 46(1): 92-94.

Haque, M.N., Haque, M.R., Parvin, A. and Hussain, M.M. 2011. Productive and reproductive performance of different crossbred cattle at Sylhet government dairy farm. Prog. Agri., 22(1-2): 47-54.

Hussain, J., Roychoudhury, R., Das, G.C., Mili, D.C. and Goswami, R.N. 2012. Reproductive performance of dairy cows under field condition of Assam state. Indian J. Anim. Res., 46(2): 180-183.

IBM Corp. Released 2020. IBM SPSS Statistics for Windows, Version 27.0. Armonk, NY: IBM Corp.

Meyer, K. 2007. WOMBAT: a tool for mixed model analyses in quantitative genetics by restricted maximum likelihood (REML). J. Zhejiang Univ. Sci. B., 8(11): 815-821.

Mondal, S.C., Alam, M.M., Rashid, M.M., Ali, M.Y. and Hossai, M.M. 2005. Comparative study on the different dairy genotypes reared in Bangladesh agricultural university dairy farm. Pak. J. Nutr., 4(4): 222-225.

NDDB. 2014. Dairying in Tamil Nadu - A statistical profile. National Dairy Development Board, Anand, Gujarat.

Rehman, Z.U., Khan, S.M., Bhatti, S.A. and Iqbal, J. 2008. Factors affecting first lactation performance of Sahiwal cattle in Pakistan. Archiv. Für. Tierzucht., 51(4): 305-317.

Singaravadivelan, A., Vijayakumar, P., Ramachandran, M., Nithiaselvi, R., Vasanthakumar, T. and Sivakumar, T. 2021. Behaviours, Health Status and Growth Performance of Crossbred Jersey Calves Reared Under Different Weaning SystemInt. J. Livest. Res., 11(3): 92-97.

Singh, J. and Singh, C.V. 2016. Genetic and phenotypic parameters of first lactation and life time traits in Sahiwal cows. J. Vet. Sci. Technol., 7: 345.

Singh, A., Singh, A., Singh, M., Prakash, V., Ambhore, G. S., Sahoo, S. K. and Dash, S. 2016. Estimation of genetic parameters for first lactation monthly test-day milk yields using random regression test day model in Karan fries cattle. Asian Australas J. Anim. Sci., 29(6): 775-81.

Singh, R.P. and Raut, K.C. 1980. Studies on performance characteristics in cattle maintained under village conditions. Indian J. Anim. Sci., 50: 619-623. 
Subramanian, A. and Ulaganathan, V. 1990. Effect of parity and environment on milk yield in crossbred cows. Cheiron, 19(4): 153-155.

Sultana, R. 1995. Quantitative analysis of reproductive performance of purebred and their crosses in the Savar Dairy Farm. M. Sc. Thesis. Dept. of Animal Breeding and Genetics. BAU, Mymensingh.

Varaprasad, A.R., Raghunandan, T., Kumar, M.K. and Prakash, M.G. 2013. Studies on the reproductive performance of Jersey $\times$ Sahiwal cows in Chittoor district of Andhra Pradesh. Int. J. Agric. Sci., 1(1): 52-57.
Vijayakumar, P., Singaravadivelan, A., Silambarasan, P., Ramachandran, M. and Churchil, R. 2019. Production and Reproduction Performances of Crossbred Jersey Cows. Vet. Res. Int., 07(02): 56-59.

Vinothraj, S., Subramaniyan, A., Venkataramanan, R., Joseph, C. and Sivaselvam, S.N. 2016. Genetic evaluation of reproduction performance of Jersey $\times$ Red Sindhi crossbred cows. Vet. World., 9(9): 1012-1017. 
